\title{
Rural Tourism within the Sustainable Development Goals : the Case of Ukraine
}

\author{
Hanna Shevchenko ${ }^{1, *}$ and Mykola Petrushenko ${ }^{1}$ \\ ${ }^{1}$ Institute of Market Problems and Economic-Ecological Research of the National Academy of Sciences \\ of Ukraine, Department of Economic Management of Natural Resources, Frantsuz'ky 29, 65044 Odesa, \\ Ukraine
}

\begin{abstract}
Research background: rural tourism is an economic and environmental activity that fits harmoniously into the concept of sustainable and inclusive development. In Ukraine, it is called rural green tourism, but in practice not all aspects of it can meet the Sustainable Development Goals 2030.

Purpose of the article: to analyze the relationship between the structures of the rural tourism goals and the SDGs, to demonstrate the evolution, possibilities of the development on the example of Ukraine's rural tourism, especially in the framework of the European Green Deal.

Methods: factor analysis - when studying the structure of the rural tourism goals and the factors that affect it, as well as when comparing it with the structure of other sustainable activities; elements of graph theory - in the graphical analysis of the Sustainable Development Goals decomposition in their projection into the plane of rural tourism.

Findings \& Value added: the structure of the rural green tourism goals in Ukraine have been harmonized with the Sustainable Development Goals 2030. Sustainability factors have been identified that allow the tourism and recreation sphere in the medium and long term perspective not only to form a competitive market for relevant services, but also to serve as an important component of the inclusive development. Factors of tourism sphere transformation due to the coronavirus pandemic are taken into consideration. The concept of the phased programming in sphere of rural tourism in Ukraine within the framework of the European Green Deal 2030 and 2050 has been improved.
\end{abstract}

Keywords: rural tourism; environment; green economy; SDGs; inclusiveness; Ukraine

JEL Classification: $L 83 ; P 25 ; Q 56$

*Corresponding author: hannashevchenko@gmail.com 


\section{Introduction}

Rural tourism is the object of transdisciplinary research and the plane of practical implementation of the Sustainable Development Goals [1]. From a scientific point of view, rural tourism is a multifaceted activity, the study of which requires integrated and integrated approaches $[2,3,4]$, the justification of its economic goals $[5,6,7]$, the disclosure of its social side $[8,9]$, the priority of its natural and ecological aspects $[10,11]$. The legal [12] and geographical [13] aspects of rural tourism have also studied separately. Within the analysis of the national economy's territorial-sectoral structure, rural tourism has direct and indirect relations to tourism and recreation, agriculture, forestry, etc. The scientific search for additional opportunities to expand the relationship between environmental and social aspects of rural tourism can increase the potential for the Sustainable Development Goals. From the point of view of consumers it is first of all about the recreational function of rural tourism $[14,15]$.

The rural green tourism has developed in Ukraine: table 1 - based on materials [16]. As we can see, this is the initial stage of its evolution. However, given the limited international travel due to the pandemic situation, there is a potential opportunity to intensify rural green tourism in Ukraine. Therefore, given the slow development of this sphere during the period of Ukrainian independence in 1991-2019, and the existence of contradictions in its development, it is important to justify the second stage of the enlargement of Ukraine's rural tourism.

Table 1. Rural tourist destinations in Ukraine, 2020

\begin{tabular}{|c|c|l|}
\hline Region & \multicolumn{1}{|c|}{$\begin{array}{c}\text { Number of tourist } \\
\text { destinations }\end{array}$} & \multicolumn{1}{c|}{ Oblasts of Ukraine } \\
\hline West & 27 & $\begin{array}{l}\text { Zakarpattya }-12 ; \text { Khmelnytsky }-11 ; \text { Ivano- } \\
\text { Frankivsk }-3 ; \text { Lviv }-1\end{array}$ \\
\hline Southern & 3 & Mykolayiv -2 ; Odesa -1 \\
\hline East & 2 & Dnipro $-1 ;$ Kharkiv -1 \\
\hline Central & 29 & $\begin{array}{l}\text { Kyiv }-13 ; \text { Poltava }-5 ; \text { Vinnytsia }-2 ; \\
\text { Cherkasy }-4 ; \text { Chernihiv }-4 ; \text { Sumy }-1\end{array}$ \\
\hline
\end{tabular}

Source: the Rural tourism data bank in Ukraine [16]

Given the above the purpose of the paper is to analyze the relationship between the structure of the rural tourism goals and the structure of the Sustainable Development Goals, on the example of Ukraine to demonstrate the evolution and prospects of the rural green tourism, in particular, within the European Green Deal.

\section{Methodology}

The conceptual basis of the study is a comprehensive approach that is applied to systems that have social, economic and environmental characteristics [17]. The following methods have been used in the paper: factor analysis (taking into account the specifics of its application in the economic sphere [18]) - when studying the structure of the rural tourism goals and the factors that affect it, as well as when comparing it with the structure of other sustainable activities; elements of graph theory [19] - in the graphical analysis of the Sustainable Development Goals decomposition in their projection into the plane of rural tourism.

The relationships between variables (classification of variables) are established on the basis of formal logic, when we synthesize the Sustainable Development Goals into aspects 
of sustainable development. The reduction in the number of variables is similar, in the opposite direction: from objectives to aspects (groups of variables).

\section{Results}

The analysis of the relationship between the Sustainable Development Goals and the goals of rural green tourism has five stages - in Fig. 1, which presents a graph of the sustainable development of rural green tourism $V(G)=\{1,2, . ., 35\}$.

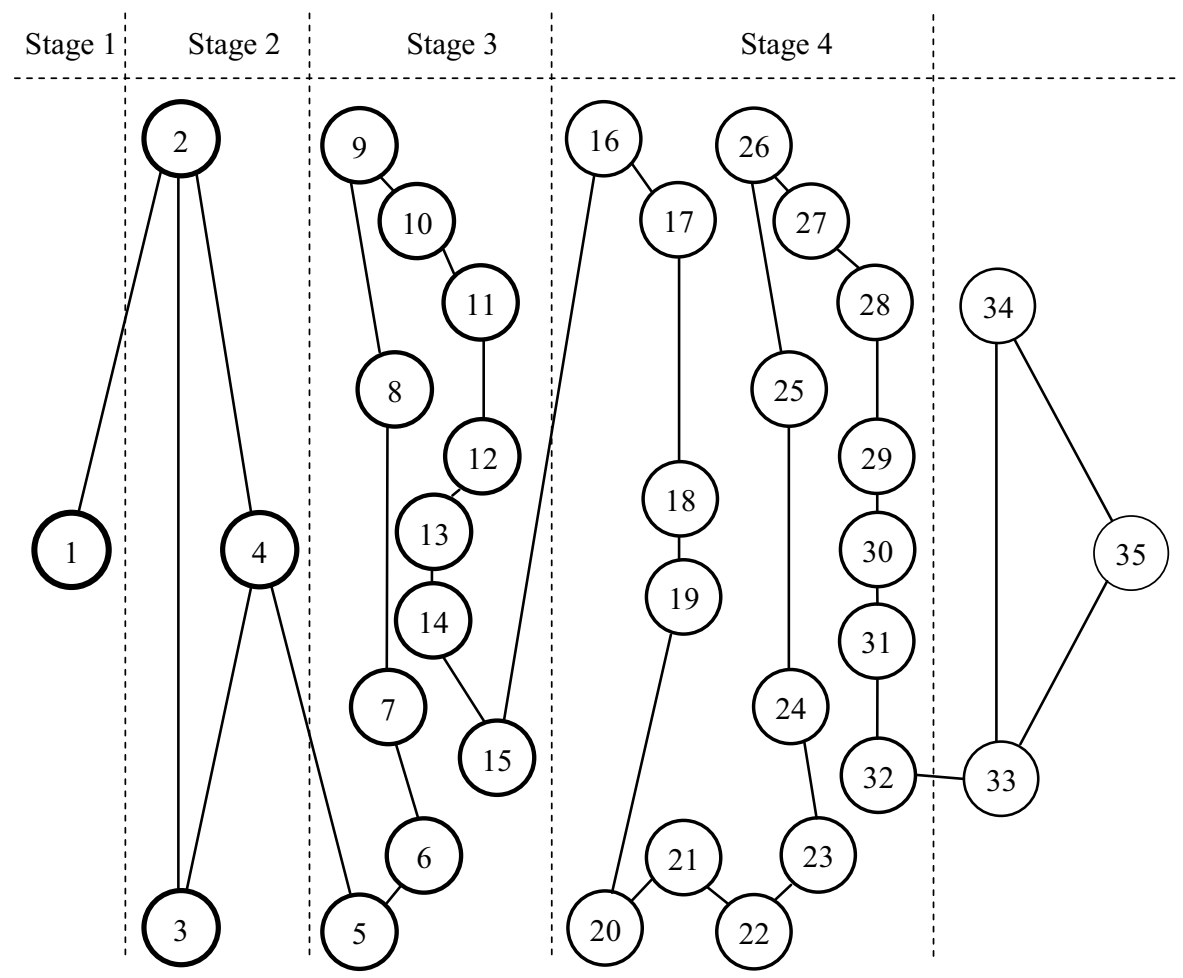

Fig. 1. Graph of the rural green tourism development goals harmonized with the Sustainable Development Goals.

Source: Developed by the authors

Stage 1 (path: 1) - the mission of sustainable development, which corresponds to the integrated goal of ensuring the well-being of society and future generations;

Stage 2 (cycle: $2-3-4-2$ ) - the decomposition of sustainable development goals into three aspects: economic, environmental and social;

Stage 3 (path: $5-\ldots-15$ ) - the rural green tourism goals relevant to the Sustainable Development Goals (11 of 17);

Stage 4 (path: $16-\ldots-32$ ) - the parameters of the sustainable development of rural green tourism (presented in table 2 - on the basis of [1]);

Stage 5 (cycle: $33-34-35$ ) - the generalization of sustainability factors of the rural green tourism development: ecological-economic factor (33) and socio-economic factor (34), closing the mission of rural green tourism (35) - a set of quality, comfortable, safe recreational and tourist services based on rural natural areas, on the basis of sustainability and inclusiveness. 
Table 2. Data for factor analysis of the compliance of the rural green tourism goals and Sustainable Development Goals 2030 in Ukraine

\begin{tabular}{|c|c|c|c|}
\hline Goals / Parameters & 2018 & 2030 & $\Delta$ \\
\hline \multicolumn{4}{|c|}{ Sustainable and inclusive agricultural activity } \\
\hline Labour productivity in agriculture, USD1,000s per employee & 10.89 & 15.00 & 4.11 \\
\hline $\begin{array}{l}\text { Share of agricultural land under organic production in the total } \\
\text { area of agricultural lands of Ukraine, } \%\end{array}$ & 0.72 & 1.70 & 0.98 \\
\hline \multicolumn{4}{|l|}{ Health and welfare } \\
\hline $\begin{array}{l}\text { Share of expenditures of the population in general spending on } \\
\text { health, \% }\end{array}$ & 48.24 & 30.00 & -18.24 \\
\hline \multicolumn{4}{|l|}{ Socio-economic development } \\
\hline Ukraine's position in the rating of Doing Business & 71 & 20 & -51 \\
\hline \multicolumn{4}{|l|}{ Innovation activity and infrastructure } \\
\hline $\begin{array}{l}\text { Rural population coverage with Internet services, subscribers } \\
\text { per } 100 \text { persons }\end{array}$ & 5 & 50 & 45 \\
\hline \multicolumn{4}{|l|}{ Sustainability of communities } \\
\hline $\begin{array}{l}\text { Area of the nature reserve fund of national importance, } \% \text { of } \\
\text { the country area }\end{array}$ & 4.10 & 8.85 & 4.75 \\
\hline $\begin{array}{l}\text { Number of cities in which the average annual concentrations } \\
\text { of major pollutants in the atmospheric air exceed the average } \\
\text { daily maximum permissible concentrations, units }\end{array}$ & 35 & 15 & -20 \\
\hline Number of employees in tourism sphere, persons & 62,585 & 100,000 & 37,415 \\
\hline \multicolumn{4}{|l|}{ Ecosystem restoration } \\
\hline Share of arable land in total area of the country, $\%$ & 53.9 & 47.0 & -6.90 \\
\hline $\begin{array}{l}\text { Share of the area of the nature reserve fund in mountainous } \\
\text { regions in the total area of the country, \% }\end{array}$ & 1.09 & 2.54 & 1.45 \\
\hline \multicolumn{4}{|l|}{ Cooperation for sustainability } \\
\hline $\begin{array}{l}\text { Net foreign direct investment (according to the balance of } \\
\text { payments), USD billions }\end{array}$ & 2.36 & 17.50 & 15.14 \\
\hline
\end{tabular}

Source: Developed based on the Voluntary National Review [1]

Given the European integration processes, Ukraine's rural tourism should be focused on the implementation of the European Green Deal 2030 i 2050 [20]. Contrary to today's pandemic crisis and its projected consequences, the rural tourism program in Ukraine, relevant to the criteria of sustainability and inclusiveness, is required, as an important part of the domestic outdoor recreation and tourism market, that fully in line with the sustainable development principles. The concept of the program includes the following main provisions:

- the setting ambitious goals, united by the mission of achieving climate neutrality (rural tourism as a tool and at the same time as an area where these goals are implemented);

- the transforming the priority of economic goals into a balance of economic, energy, social and environmental goals;

- the functioning of the sphere on the principles of circular economy;

- zero pollution of the environment, where rural tourism services are provided;

- the extending the "farm to fork" approach to the rural green tourism, etc.

The stages of the rural green tourism development are as follows:

- the development during the pandemic crisis (emphasis on safety and comfort in accordance with hygienic norms and standards); 
- the development in the post-pandemic period (increase in investment in the development of tourist routes and support of estates engaged in the tourism business);

- the development by 2030 (creation of a modern network of the rural green tourism, focused on the services provision of European level);

- the development in the period 2030-2050 (final solution of environmental, energy and social issues related to the functioning of the rural green tourism network, on the basis of sustainability and inclusiveness).

\section{Discussion and conclusion}

The evolution of the rural green tourism in Ukraine, when widely considered, has been going on for centuries. For Ukraine, it is traditional to travel in the countryside and rest in the natural environment. With a modern view of agritourism, it is a tool for effective rural development [21]. After the restoration of a stable state in the economy and society, when the pandemic crisis ends, it is advisable to use factor analysis as a statistical intelligence and confirmation tool to work with statistics relevant to sustainable tourism and outdoor recreation. In the sphere of rural tourism, given the effects of coronavirus, it is advisable to collect data on how potential vacationers and tourists see the level of comfort, safety and impressions associated with being in the natural environment, on the basis of a special survey.

The results obtained in this study allow harmonizing the structure of the rural green tourism goals in Ukraine with the Global Goals 2030 in the context of identifying potential areas of sustainable development in the postcoronavirus world. In the paper sustainability factors have been also identified that allow the tourism and recreation sphere in the medium and long term perspective not only to form a competitive market for relevant services, but also to serve as an important component of the inclusive development. Factors of tourism sphere transformation due to the coronavirus pandemic are taken into consideration. The concept of the phased programming in sphere of rural tourism in Ukraine within the framework of the European Green Deal 2030 and 2050 has been developed.

\section{References}

1. Sustainable Development Goals Ukraine (2020) Voluntary National Review. Retrieved from: https://sustainabledevelopment.un.org/content/documents/26295VNR_2020_Ukraine_ Report.pdf

2. Chase, L. C., Stewart, M., Schilling, B., Smith, B., Walk, M. (2018). Agritourism: Toward a conceptual framework for industry analysis. Journal of Agriculture, Food Systems, and Community Development, 8(1), 13-19. https://doi.org/10.5304/jafscd.2018.081.016

3. Lane, B., Kastenholz, E. (2015). Rural tourism: the evolution of practice and research approaches - towards a new generation concept? Journal of Sustainable Tourism, 23:89, 1133-1156. https://doi.org/10.1080/09669582.2015.1083997

4. Rauniyar, S., Kant Awasthi, M., Kapoor, S., Mishra, A. K. (2020). Agritourism: structured literature review and bibliometric analysis. Tourism Recreation Research. https://doi.org/10.1080/02508281.2020.1753913

5. Joo, H., Khanal, A., Mishra, A. (2013). Farmers' participation in agritourism: Does it affect the bottom line? Agricultural and Resource Economics Review, 42(3), 471-490. https://doi.org/10.1017/S1068280500004949 
6. Ryglová, K., Rašovská, I., Šácha, J. (2017). Rural tourism - evaluating the quality of $\begin{array}{llll}\text { destination. European } \quad \text { Countryside, } & \text { 769-788. }\end{array}$ https://doi.org/https://doi.org/10.1515/euco-2017-0043

7. Yachin, J. M., Ioannides, D. (2020). "Making do" in rural tourism: the resourcing behaviour of tourism micro-firms. Journal of Sustainable Tourism, 28:7, 10031021. https://doi.org/10.1080/09669582.2020.1715993

8. Petrushenko, M. M., Shevchenko, H. M., Vernydub, N. O., Kravchenko, O. V., Ovcharova, N. V. (2019). The forming of industrial and national natural parks networks in Ukraine based on the principles for responsible investment. Financial and credit activity: problems of theory and practice, 4(31), 221-229. https://doi.org/10.18371/fcaptp.v4i31.190880

9. Shevchenko, H., Petrushenko, M., Burkynskyi, B., Khumarova, N., Opanasiuk, Y. (2020). Management of wellness and recreation in urban agglomerations. Problems and Perspectives in Management, 18(1), 231-241. https://doi:10.21511/ppm.18(1).2020.20

10. Petrushenko, M. M., Shevchenko, H. M. (2013). Management of ecological-economic conflicts in the context of the optimal mechanisms theory for the resources allocation. Actual Problems of Economics, 3, 186-192.

11. Prokopenko, O. V., Petrushenko, M. M. (2013). Systems-synergetic thinking to the environmental conflicts management at the territorial level. Marketing and Management of Innovations, 1, 254-266. Retrieved from : https://mmi.fem.sumdu.edu.ua/en/journals/2013/1/254-266

12. Shevchenko, H. M., Pakhomov, V. M., Petrushenko, M. M. (2016). Economic and legal issues of rural and recreational land use in Ukraine. Economic Annals-XXI, 1 2(156), 54-58. https://doi.org/10.21003/ea.V156-0012

13. Sadowski, A, Wojcieszak, M. M. (2019). Geographic differentiation of agritourism activities in Poland vs. cultural and natural attractiveness of destinations at district level. PLoS ONE, 14(9): e0222576. https://doi.org/10.1371/journal.pone.0222576

14. Petrushenko, M., Shevchenko, H., Burkynskyi, B., Khumarova, N. (2019). Gametheoretic model of investment in inclusive wellness and recreation by regions in Ukraine. Investment Management and Financial Innovations, 16(4). 382-394. http://dx.doi.org/10.21511/imfi.16(4).2019.32

15. Shevchenko, H. M. (2017). Regulatory policy and optimization of investment resource allocation in model of functioning recreation industry. Baltic Journal of Economic Science, 3(1), 109-115. http://dx.doi.org/10.30525/2256-0742/2017-3-1-109-115

16. Green tourism (2020). Rural tourism data bank in Ukraine. Retrieved from: http://ruraltourism.com.ua

17. Wang, R., Li, Feng, Hu, D., Li B. L. (2011). Understanding eco-complexity: Social-Economic-Natural Complex Ecosystem approach. Ecological Complexity, 8(1), 15-29. https://doi.org/10.1016/j.ecocom.2010.11.001

18. Olsen, B. M., Garb, G. (1965). An application of factor analysis to regional economic growth. Journal of Regional Science, 6(1), 51-56. https://doi.org/10.1111/j.14679787.1965.tb01305.x

19. Friesz, T. L., Bernstein, D. (2016). Elements of graph theory. In: Foundations of network optimization and games. Complex networks and dynamic systems, vol. 3, Springer, Boston, MA, 75-120. https://doi.org/10.1007/978-1-4899-7594-2_3

20. European Commission website (2020). A European Green Deal. Retrieved from : https://ec.europa.eu/info/strategy/priorities-2019-2024/european-green-deal_en

21. Rural tourism (2019). Information and analytical portal of the AIC of Ukraine. Retrieved from: https://agro.me.gov.ua/ua/napryamki/rozvitok-silskihteritorij/silskij-turizm 